\title{
Financial stability and Solvency of Algerian banks, application of stress tests from 2012 to 2016
}

https://doi.org/10.21272/fmir.2(4).57-67.2018

\section{Bouchetara Mehdi}

Dr., Research Centre in Applied Economy for Development CREAD, Algeria

\begin{abstract}
The purpose of this article is to provide a new vision, a realistic and precise application in risk management within the Algerian banking sector. The purpose of the stress test is to anticipate both the risks and the capital required for the coming months or years, taking into account possible shocks, whether they are economic or based on assumptions internal to the bank.
\end{abstract}

This article aims to assess the stability of the Algerian banking system in order to examine the resilience of the 12 public and private banks between 2012 and 2016. The methodology used is based on a macro-prudential (top-down) approach by mobilizing data from the accounting and financial documentation of Algerian banks. The Cooke ratio is the key indicator used as a measure reflecting the solvency of banks.

The results show that the Algerian banking system is showing increased resistance to shocks before and after the drop of oil prices. Algerian banks are solvent in the short and medium term. Stress tests showed their performance, reflecting the exact position of capital after a pessimistic shock.

The diversity of the shocks represents the strong point of the stress tests; it is indeed a principle of adaptation with any macro-microeconomic environment. It is enough to interpret the results in a clear and comprehensive way to make a strategic decision. Resistance testing is an effective tool in decision-making. They appear in different approaches or standards, whether qualitative or quantitative.

In Algeria, stress tests are far from performing well due to several reasons. A weak banking data infrastructure limits the optimal application of stress tests. Hence, insufficient training of banking staff to master the tools for analysis and application of stress tests. That is why, Algerian monetary supervisors should continue to progress in the area of risk management, applying various mechanisms.

Keywords: banking risk management, prudential rules, macroprudentiel approach, bale 3, stress test, algerian banks.

JEL Classification: G01, G21, G32.

(C) The Authors, 2018. This article is published with open access at Sumy State University.

Cite as: B. Mehdi. (2018). Financial stability and Solvency of Algerian banks, application of stress tests from 2012 to 2016, Financial Markets, Institutions and Risks, 2(4), 57-67. https://doi.org/10.21272/fmir.2(4).57$\underline{67.2018}$

\section{Introduction}

For more than a decade, supervisors and financial institutions have increasingly resorted to stress tests to assess risks on the financial system. The tests help to measure the impact of the various risks to which banks are exposed. They also help to elucidate their transmission channels. Initially, the tests put in place have focused much more on the solvency risk. The financial crisis of 2007-2008 highlighted the liquidity risk and the overflow effects related to the interdependence of banking institutions.

In 2014, Algeria participated in an analysis conducted by the IMF under the Financial Sector Assessment Program (FSAP) ${ }^{2}$. The results of the stress tests indicate that the concentration of credit, particularly that of loans are the main banking risks, and that public banks are the most vulnerable. The latter are in particular, highly exposed to large state-owned companies in the manufacturing, construction and trade sectors, and therefore subject to company-specific and sector-specific shocks. That being said, Algeria's external and fiscal

\footnotetext{
${ }^{2}$ The report on the financial system stability prepared by an IMF service team. This report leans on the work of a common mission PESF of the IMF and the World bank which took place in Algeria in September 2013. The Financial system stability assessment was completed in January 9, 2014.
} 
room for maneuver is substantial, thanks to high oil prices and it has been observed that the state is able and willing to support the banks.

Most studies on stress tests use macroeconomic and financial parameters but do not adopt data typical to the bank financial criteria. They therefore do not admit studying the role played by specific elements to the banking sector in triggering crises. The primary objective of this article is therefore to test, alongside macroeconomic and financial parameters, the contribution of banking standards in the analysis of financial stability. Secondly, we also seek to determine the causes that contributed above all to the weakening of the Algerian banking system, then the outbreak of the crisis and finally, the persistence of the crisis over time from an accounting-analytical model.

In fact, previous research showed great obstacles in capturing crisis phases with accuracy and in particular the precise outbreak time. This approach highlights the problem of bias related to crisis identification. This bias appears when we consider the phases following the crisis, which are neither phases of stability nor phases of crisis.

The difficulties, which exist in studying banking crises or the vulnerability of the banking system, are the inadequacy of a consensual model that is widely accepted. Through the studies of Eichengreen and Arteta $(2000)^{3}$, the main logic can explain the non-convergence of empirical results, particularly on the question of the causes of bank failures. Moreover, while the majority of economists are not unanimous about the causes of crises, the fractional reserve model is generally considered the main cause of bank default. This model, which allows banks to deploy a fraction of deposits to finance high risky credits and investment projects, is analyzed in the theory of Diamond and Dybvig $(1983)^{4}$.

In the first instance, we define the stress tests and explain their usefulness to evaluate the risks. As a second step, we will unfold the theoretical and empirical works treating our object of research. In the third phase, we will present and discuss our results before concluding and opening up some future lines of research.

The situation has changed since 2014 as oil prices have fallen significantly. Has this exogenous shock had a negative impact on the financial system as a whole?

\section{Stress Testing: definition and uses}

Stress tests are instruments used by banks to manage risks internally and which allow authorities to measure the effects that serious but plausible negative shocks could have on the capital level of banking institutions (Basel Committee on Capital Markets) (banking supervision, 2009). They were gradually developed after the 2007 systemic financial crisis, which affected the banking sector. The banking requirements were reinforced by the mechanism of stress tests not only in the United States and Europe, but also on a global level.

The first objective of the stress tests is to measure the temporary impact of the severe and pessimistic, but rather plausible, scenarios on financial stability in general and banking more precisely. The scenarios are based on shocks and macro-microeconomic simulations. Stress tests identify the value of capital adequate to withstand and absorb losses resulting from scenario applications. They give a well-defined analysis of the contagion effects as well as the results related to the dysfunction of the interbank market or liquidity risks. Generally, the implementation of classic stress tests is done on a horizon of 2 years to 5 years for banks. ${ }^{5}$

The stress tests have a double objective not only to see if the financial institutions can withstand the selected shocks, but also to evaluate the capitalization strategies of banks in critical situations with the implementation of potential measures of recapitalization, restriction and sharing of dividends or the redemption of shares. Transparency is one of the most important objectives of bank stress tests, when publishing impact results by providing the financial markets with sufficient information.

Since 2009, several financial institutions in Europe and the United States had been forced by supervisory authorities to follow rigorous stress testing programs. Even institutions that are far from danger should apply some forms of stress tests. However, recent economic events have shown that the importance and performance

\footnotetext{
3 EICHENGREEN B, ARTETA C, 2000, Banking Crises in Emerging Markets: Presumptions and Evidence, Institute of Business and Economic Research, Center for International and development Economics Research, University of California.

${ }^{4}$ DIAMOND D.et DYBVIG P., 1983, Bank runs, Deposit Insurance, and liquidity, Federal Reserve Bank of Minneapolis, Quarterly Reviews, Vol. 24 $\mathrm{N}^{\circ} 1$.

${ }^{5}$ Vincent MARTIN, Santiago TAVOLARO and Sandrine VIOL, January2013, Stress tests on the bank system and the insurance bodies in France, Bank of France Magazine, N11, P7.
} 
of stress tests are often insufficient. These deficiencies, combined with new liquidity requirements and FED rules, should inspire several banks to improve their resilience. ${ }^{6}$

The stress tests allow measuring the impact of micro-macroeconomic shocks on the stability of the financial system in general and banking system in particular. On the other hand, the advanced stability indicators of banking crises only determine the probability that banks are affected by the most adverse macroeconomic shocks. ${ }^{7}$

Generally, supervisory authorities and monetary evaluators follow four to five steps to apply stress tests effectively. The following table summarizes the key steps in applying the stress tests:

Table 1. Steps to follow in order to conduct efficient resistance tests

\begin{tabular}{|l|l|}
\hline \multicolumn{1}{|c|}{ Steps } & \multicolumn{1}{c|}{ Définitions } \\
\hline $\begin{array}{l}\text { Step 1: Definition of analysis field and identification of } \\
\text { vulnerability. }\end{array}$ & $\begin{array}{l}\text { - Selection of all the financial institutions concerned. } \\
\text {-Determine whether the assessment of risk exposure should cover } \\
\text { the entire financial system or whether the analysis should be } \\
\text { limited to the most important institutions. }\end{array}$ \\
\hline Step 2: design and benchmarking of scenarios & $\begin{array}{l}\text { - Define scenarios that specify various events that may affect the } \\
\text { operation of the bank. } \\
\text { There are a number of elements involved in the design of any } \\
\text { stress scenario, including the choice of the type of risks to be } \\
\text { analyzed, whether the risk factors are unique or multiple, the } \\
\text { parameter (s) to be shocked, the scenario approach (based on } \\
\text { historical or hypothetical scenarios) and over what time horizon. }\end{array}$ \\
\hline Step 3: Assessment of vulnerabilities in face of risk factors & $\begin{array}{l}\text { Measuring the impact of macroeconomic shocks on the stability } \\
\text { of the financial system using a number of indicators. It is within } \\
\text { this framework that financial soundness indicators (FSIs) are used } \\
\text { to quantify the systemic importance of different sources of risk. }\end{array}$ \\
\hline Step 4: Interpreting the results & $\begin{array}{l}- \text {-Analysis and discuss the results of stress tests. They can be } \\
\text { facilitated and improved by a clear presentation of the basic } \\
\text { assumptions and judgments, used to generate the results. } \\
\text { The results are mainly expressed in terms of losses on the } \\
\text { portfolio, capital losses, number of institutions in default, need for } \\
\text { reinvestment of capital. } \\
- \text { The supervisor will interprethis results and will be able to assess } \\
\text { the institution's resilience to risk and thus decide how to act. }\end{array}$ \\
\hline Step 5: Publication of results & $\begin{array}{l}\text { - Honor the respect of the criterion of transparency and have } \\
\text { reliable results. }\end{array}$ \\
\hline
\end{tabular}

Source: Prepared by the author.

\section{Review of the litterature}

The sovereign crisis of 2010 unveiled the reality of the interactions between the financial system and the fiscal position of the countries. Shocks and crises shook first, the financial system, and then spread through different channels of transmission to all economies, specifically to the most fragile economies.

The social damage, the unemployment, the deficits, the public debt and the imbalances of the financial system, generated by this crisis were very serious. These consequences imply overcoming of traditional methods that favor following the financial strength institutions taken individually. This means adopting a macroprudential policy of the financial system as a whole by analyzing interactions with different economic sectors and their effects on financial stability. In this respect, stress tests are a necessary lever for analyzing the relationship between macroeconomic changes and the stability of the financial system.

The work of Van Den End (2008) ${ }^{8}$ presents a macroeconomic model of stress tests for market risks and liquidity risks, of which were the main causes of the last financial crisis of 2008. The model was applied in July 2007 on 82 Dutch banks including foreign banks over a period of one month. The model takes into account the first and second round of shock effects, induced by the attitudes of heterogeneous banks, and reputation effects. The liquidity risk impact is simulated by Monté Carlo's ${ }^{9}$ approach. This generates the

\footnotetext{
${ }^{6}$ SAS reports, Accenture Management consulting, 2012, P2.

7 Olivier DE BANDT, Vichett OUNG, 2004, Statement of the stress tests conducted on the French Banking System, P57.

8 Jan Willem van den End, Op.cit, P5

${ }^{9}$ The Monte- Carlo simulation method allows introducing a statistical approach of the risk in a financial decision. It consists of isolating a number of Key-variables from the analysis, such as the turnover or the margin, , and allocate them with a probability distribution:. For each one of these factors, a large number of random draws is carried out in the probability distribution previously determined, in order to find the probability of occurrence of each of the results.
} 
distribution of liquidity for each type of scenario, including the likelihood of a liquidity shortage. The results of the study show that second-round shock effects have more impact than first-round shock effects.

This reinforces initiatives aiming to improve the management of bank liquidity risk and liquidity buffer. This could also prevent financial stability. Peristiani, Morgan and Savino' (2010), focused on the value of stress tests by producing important information for banks and markets. The study involved 19 major US banks using standard estimation methods, such as the least square method. The results of this study suggest that stress tests help to calm the financial panic by producing important information on the banks' situation.

Trinnou $^{10}$ (2014) applied stress tests on the banking sector in WAEMU ${ }^{11}$ countries by testing banks' resistance to severe macroeconomic shocks related to credit risks over the period 1995-2011. First, he simulated macroeconomic scenarios based on a Vectorial Auto Regressive (VAR) model.

The latter were based on historical facts and banking crisis experiences during the period 1980-1990 in the member countries of the zone. In a second step, the scenarios were simulated on the real GDP growth rate and the real exchange rate, taken separately and in a mixed way. The tests were conducted on the capital adequacy ratio as an indicator used to test the banks' resistance by comparing it to a minimum of $8 \%$ required to cover the risks.

The results showed that the banking sector of the WAEMU countries is able to withstand macroeconomic shocks after the implementation of the stress tests because the capital adequacy ratio ${ }^{12}$ of the banks always remained higher than $8 \%$ even after observing a significant decline following shocks. The author also confirms that, despite the requirements of prudential rules, banks suffer severe shocks. The CAR (cook ratio) is starting to deteriorate and lead banks to a bankruptcy that is still resilient to shocks ${ }^{13}$.

The Bank of France conducted stress tests with the assistance of the International Monetary Fund (IMF) in the first half of 2004 to assess the stability of the financial system, and test the banking system's resilience to macroeconomic shocks over two years. The scenarios were based on the following assumptions: the occurrence of an oil shock, an exchange rate crisis, a fall in stock prices and a recession. The shocks were focused on three axis: market shocks, liquidity shocks and credit quality shocks. Several methods were used in the example of SAABA ${ }^{14}$ during simulations of banking portfolio deterioration.

The Mascot ${ }^{15}$ model that models private sector credit demand by focusing on the link between private sector demand for credit, household and business investment demand, and interest rates ${ }^{16}$. The profitability model is a panel model calibrated on all banks. This model is proposed by Flannery ${ }^{17}(1981)$ who develops a method for estimating the average maturity of assets and liabilities for a sample of large banks.

The regression model is tested to determine if fluctuations in market rates have a significant impact on bank profitability. The results show that large banks are hedged against market rate risk by assembling portfolios of assets and liabilities with similar average maturities. Two approaches have been used, one called top-down method, also called top-down process, which consists first of all of doing a macroeconomic analysis of all sectors. The other called bottom-up also called stock picking is a type of portfolio management and macroeconomic analysis. ${ }^{18}$

The results of these stress tests have shown that the French banking sector can withstand market shocks. Its profitability and solvency are still positive in comparison with the minimum regulatory level of $8 \%$, which is a margin largely sufficient. On the other hand, banks suffer a deterioration of their banking portfolios. ${ }^{19}$ The shock that seemed very severe is that of the slowing global demand by inducing almost zero growth in the following two years, with a decline in the solvency ratio of one level compared with Basel I, and two levels

10 Mathieu Gbêmèho TRINNOU, 2012, Implementation of the macroprudential « stress-test » of the banking credit risk in the West African Economic and monetary Union (UEMOA), Training, Research and Development Studies Centre (CEFRED) Faculty of Economic Science and Management (FASEG) University of d'Abomey-Calavi, Benin, P 1-39.

${ }^{11}$ L'UEMOA is made up of eight countries: Benin, Burkina Faso, Ivory Coast, Guinea Bissau, Mali, Niger, Senegal and Togo.

${ }^{12}$ Solvency Ratio: It brings regulatory (numerator) capital for weighted (denominator) risks. It must at least equal to $8 \%$

${ }^{13}$ Mathieu Gbemèho TRINNOU, Op-Cit, P2.

${ }^{14}$ SAABA: Expert système of the Banking Commission General Secretariat for the early detection of banking institutions in difficulty.

${ }^{15}$ Mascotte, a model for analyzing, forecasting and simulating the quarterly situation, is an econometric model used by the Bank of France to produce whole macroeconomic projections taking into account the interactions between variables at the macroeconomic level..

${ }^{16}$ Baghli M, Brunhes-Lesage V, Bandt O, Fraisse H and Villetelle J-P, Mascot, 2004, Quarterly conditons Analysis and Forecast Model, Bank of France, Study and Research Notes, $n^{\circ} 106$, PP 63-86.

${ }^{17}$ Flannery M.J, 1981, Market interest rates and commercial bank profitability: An empirical investigation, Journal of Banking and Finance, 1085-

1101 .

${ }^{18}$ http://www.abcbourse.com/apprendre/19 bottom up top down.html, consulted on the 12/12/2016.

19 OP. CIT, Olivier DE BANDT, Vichett OUNG PP 64-71. 
with Basel II, the banks' results were down by almost 35\% compared to the expectations at the end of 2005 . The majority of French banks had a margin largely sufficient to withstand and absorb such a shock. The remaining shocks had a small effect on profitability and bank solvency.

\section{Empirical study: application of stress tests on the algerian financial system}

In this section we present the methodology for implementing macro-prudential stress tests for liquidity risk, credit risk, interest rate risk and currency risk, as well as data and their sources. This section examines the method of calculating stress tests and the proportions that these tests take in the financial evaluation of banks. Generally, two methods of calculation are used: one econometric and the other analytic. Our study will be based on the latter. The method consists of implementing a set of techniques giving the possibility to synthesize and analyze from an economic and financial point of view the accounting documents of the banks.

We used the Cihak (2007) ${ }^{20}$ model for solvency resistance testing, which is essentially limited to sensitivity analyzes on Excel support. We followed a top-down approach to test all public and private banks. We also followed the steps taken in the last report published in 2014 by the $\mathrm{IMF}^{21}$.

Before proceeding with the application of stress tests, we will give an overview of the situation of Algerian banks.

2.1 The financial situation of Algerian banks. Currently, the banking system in Algeria is made up of twenty-nine (29) banks and financial institutions having their head offices in Algiers. The banks and approved financial institutions are distributed as follows: ${ }^{22}$ - Six (6) public banks, - Fourteen (14) private banks with foreign capital, - Nine financial institutions (9),

Private Banks, whose capital is foreign, are mainly based on international trade credits, even if the establishment of a threshold for trade finance costs, translated into the installation of interests subsidy instruments in favor of small and medium-sized enterprises, can push private banks to redirect more and more their activities towards the emerging sector of small and medium-sized enterprises. Public banks remain the main player in the Algerian financial sector. They had $85 \%$ of the total assets of the banking system in 2016, and continue to play the crucial role of fund provider for privileged public investments. According to the International Monetary Fund, Algerian public and private banks appear to be sufficiently capitalized, profitable and liquid, mainly due to State assistance. ${ }^{23}$

Asset quality: Assets are sufficient to cover more than $70 \%$ of nonperforming loans.

Capital: they are of high quality (ordinary shares represent $73 \%$ of regulatory capital), but the financial lever is increasing. Public banks have always had support from the state, which reduced nonperforming loans from $22 \%$ in 2012 to $9.5 \%$ in 2004.

$>$ In the case of private banks, the higher degree of capital is the minimum requirement.

> Profitability: Algerian banks' profitability is up compared to other neighboring countries, as Algerian banks have put an end to nonperforming loans, not by putting them off balance sheet, but by transferring the initial loan as part of recurrent recapitalizations by the State. Interest margins contribute to $70 \%$ of the operating income.

Liquidity: Algerian banks are liquid, 48\% of assets in 2015 are liquid, fully offsetting deposits of small customers who make up 55\% of liabilities. The liquidity held by a public bank is essentially high due to its classic role in hydrocarbon export operations.

2.2. Resistance Tests in Algeria. Several stress tests were conducted to examine the stability and solvency of the banking sector in the face of risks. Banking data on nonperforming loans were available whilst short. Resistance tests were conducted to analyze the fragility of Algerian banks, instead of solvency tests in a macroeconomic scenario. Two approaches were used when applying stress tests on Algerian banks. A topdown approach applied to 20 Algerian banks and bottom-up approaches applied to the 6 public, banks on the basis of the banking exercises of the year 2012 .

The pessimistic scenarios were based on the assumption of an oil shock, a slowdown in the global economy, by referring to the latest available projections of the IMF outlook of global economy. The stress tests applied

\footnotetext{
${ }^{20}$ Martin Čihák, Introduction to Applied Stress Testing, IMF Working Paper, WP/07/59, March 2007, 5-76.

21 FMI's report No. 14/161, Algeria, Financial Stability Assessment.

$22 \mathrm{https}$ ://www.researchgate.net/publication/276268740 consulted on 20/12/2017.

23 FMI's Report No. 14/161, Financial System Stability Assessment.
} 
by the International Monetary Fund in 2014 on the Algerian banking system were limited by the lack of historical data. Also, there is no information on the maturity distribution of assets and liabilities and, in the absence of a long time series of historical nonperforming loans.

The results of stress tests published by the International Monetary Fund in 2014 show that credit risk is the main banking risk, and that public banks are the most vulnerable. In the scenario of credit risk based on a 10 points increase of non-performing loans percentage, the solvency ratio of three state-owned banks that hold $28 \%$ of total assets, falls below the regulatory minimum of $8 \%$, but they remain solvent. TThe three largest borrowers in the public sector account for $40 \%$ of total loans. A default scenario for these debtors would lead to the insolvency of six banks, which shows that the concentration risks are high. The main stress tests carried out by the International Monetary Fund and the Bank of Algeria were based mainly on three axes: ${ }^{24}$

Table 2. Tests used by the IMF and the Bank of Algeria

\begin{tabular}{|l|l|}
\hline \multicolumn{1}{|c|}{ Type des tests } & \multicolumn{1}{c|}{ Results and analyzes } \\
\hline Liquidity risk resistance test & $\begin{array}{l}\text { Performed to test the ability of banks to cope with excessive withdrawals of } 5 \text { to } 10 \% \text { per day for five days. } \\
\text { The results showed that banks could cope with pressure on deposits for five days because they had a large } \\
\text { amount of liquid assets. In 2012, total liquid assets were 108\% of current liabilities. Banks have sufficient } \\
\text { liquidity buffers to withstand a liquidity shock, while interest rate and currency shocks do not have an impact } \\
\text { on the banking sector. }\end{array}$ \\
\hline Interest rate risk resistance test. & $\begin{array}{l}\text { The results published by the International Monetary Fund and the Bank of Algeria show that the impact of } \\
\text { these shocks is not important to a fluctuation of parallel rise in interest rates of 400 basis points, because they } \\
\text { do not have long-term financial tools. }\end{array}$ \\
\hline Exchange rate resistance test & $\begin{array}{l}\text { The exchange rate has an insignificant impact because banks have low open foreign exchange positions, and } \\
\text { the indirect effects are limited because non-hydrocarbon exports are not sufficiently developed. Thus, private } \\
\text { banks are more resilient to various multisectoral shocks than public sector ones. }\end{array}$ \\
\hline
\end{tabular}

Source : Rapport FMI (2014), op cité.

The banks concerned by the resistance tests are 20 banks, of which 6 in the public sector and 14 in the private sector. The statistics and regulatory ratios used in our study relate to the years between 2012- 2016. The calculations were done on an Excel spreadsheet. 6 items were constructed: Input data, liquidity risk, credit risk, exchange rate risk, interest rate risk, scenarios.

The objective of our approach is to identify the potential vulnerabilities of the Algerian banking sector, to a certain number of exceptional but plausible risk factors. Thanks to the financial analysis method, which consists of evaluating regulatory data and ratios, particularly in our case the solvency ratio, we have reached the results presented in the following tables and graphs:

Table 3. Banks' Regulatory Indicators. Unit: AD

\begin{tabular}{|l|c|c|c|c|c|}
\hline \multicolumn{1}{|c|}{ Regulatory Indicators } & 2012 & 2013 & 2014 & 2015 \\
\hline Capital & 2258,4 & 2341,1 & 2754,2 & 3167,3 & 3484,1 \\
\hline Regulatory capital & 1150.15 & 1232.50 & 1705,90 & 2256.03 & 2733.42 \\
\hline Risk Weighted Assets RWA & 9651.28 & 10888.83 & 17213.75 & 17213.58 & 18434.39 \\
\hline $\begin{array}{l}\text { Solvency Ratio } \\
\text { CAR }\end{array}$ & $23.4 \%$ & $21.5 \%$ & $16.0 \%$ & $18.4 \%$ \\
\hline
\end{tabular}

Source: Bank of Algeria.

\subsection{Tests and scenarios}

\subsubsection{Liquidity Risk}

\subsubsection{Scenarios}

Daily withdrawals of (35\%) of sight deposits and (15\%) and term deposits for 5 consecutive days.

Disposal of assets in order to face withdrawals.

Table 4. Liquidity stress calculations. Based on the days of the years 2012-2013-2014-2015-2016. Unit: In AD

\begin{tabular}{|l|c|c|c|c|c|}
\hline \multicolumn{1}{|c|}{ Year } & 2012 & 2013 & 2014 & 2015 & 2016 \\
\hline Sight deposits & 4855,5 & 5033,1 & 5921,3 & 6809,5 & 6513,4 \\
\hline Term deposits & 3348,6 & 3471,1 & 4083,7 & 4696,3 & 4492,1 \\
\hline Liquid assets & 4517,5 & 4682,7 & 5509,1 & 6335,5 & 6060,0 \\
\hline $\begin{array}{l}\text { (90\%) available per day } \\
\text { Max of liquid assets converted in cash. }\end{array}$ & & & & & \\
\hline Non-liquid assets & 5303,2 & 5497,2 & 6467,3 & 7437,4 & 7114,0 \\
\hline (1\%) Available per day & & & & & \\
\hline
\end{tabular}

Source: Bank of Algeria.

${ }^{24}$ FMI' Annual Report, 2014. 
Table 5. Main results after the liquidity stress Based on the data of the years 2012-2013-2014-2015-2016.

Unit: In AD

\begin{tabular}{|c|c|c|c|c|c|}
\hline \multicolumn{6}{|c|}{ Total of the deposits withdrawals during 5 days } \\
\hline Year & 2012 & 2013 & 2014 & 2015 & 2016 \\
\hline Day & 2201.6 & 2282.2 & 2684.9 & 3087.6 & 3396.4 \\
\hline 2 days & 1531.6 & 1587.6 & 1867.8 & 2148.0 & 2362.8 \\
\hline 3 days & 1080.9 & 1120.5 & 1318.2 & 1515.9 & 1667.5 \\
\hline 4 days & 775.1 & 803.5 & 945.3 & 1087.1 & 1195.8 \\
\hline 5 days & 565.6 & 586.2 & 689.7 & 793.2 & 872.5 \\
\hline \multicolumn{6}{|c|}{ Total of the maximum assets converted in cash } \\
\hline Year & 2012 & 2013 & 2014 & 2015 & 2016 \\
\hline Day & 4119.7 & 4270.4 & 5024.0 & 5777.6 & 6355.4 \\
\hline 2 days & 459.0 & 475.8 & 559.8 & 643.8 & 708.1 \\
\hline 3 days & 92.6 & 96.0 & 112.9 & 129.8 & 142.8 \\
\hline 4 days & 55.5 & 57.5 & 67.7 & 77.9 & 85.6 \\
\hline 5 days & 51.3 & 53.2 & 62.6 & 72.0 & 79.2 \\
\hline \multicolumn{6}{|c|}{ Flux net (net cash flow ) } \\
\hline year & 2012 & 2013 & 2014 & 2015 & 2016 \\
\hline day & 4778.3 & 4953.1 & 5827.2 & 6701.3 & 7371.4 \\
\hline 2 days & 1987.5 & 2060.2 & 2423.8 & 2787.4 & 3066.1 \\
\hline 3 days & 1173.6 & 1216.5 & 1431.2 & 1645.9 & 1810.5 \\
\hline 4 days & 830.7 & 861.1 & 1013 & 1165.0 & 1281.4 \\
\hline 5 days & 616.9 & 639.5 & 752.3 & 865.1 & 951.7 \\
\hline \multicolumn{6}{|c|}{ Liquid ( $1=$ yes $)(0=$ No $)$} \\
\hline year & 2012 & 2013 & 2014 & 2015 & 2016 \\
\hline Results & 1 & 1 & 1 & 1 & 1 \\
\hline
\end{tabular}

Source: Prepared by the author.

Interpreting. We have noticed a significant excess liquidity in the banking sector since 2012. After subjecting the banking sector to daily withdrawals of $35 \%$ of deposits and $15 \%$ in term for 5 consecutive days, we find that this test does not have a negative impact on banks, despite the accumulated withdrawals of these 5 days.

According to these results, the Algerian banking system shows an increased resistance to shocks, this is due to the situation of excess liquidity, which has lasted in Algeria since 2012. This one is supplied, on the one hand, by the importance of the deposits of the Algerian hydrocarbons sector. On the other hand, by the result of the increase in the collection of personal savings, which is growing at an average rate close to $20 \%$ in recent years, stimulated by both the injection of revenues from public stimulus plans, and the banking system of the economy.

However, these reserves are not the result of hard work, but of an ephemeral resource that is hydrocarbons. It is therefore important to give strategic importance to genuine development, in order to ensure effective management of institutions through better management.

\subsubsection{Credit risks}

\subsubsection{Scenarios}

Subordination of (10\%) of performing credits from category (1) to category (4). Gradual downgrading of credits from the category (c) to the other :(20\%) from $\mathrm{c} 1$ to $\mathrm{c} 2,(30 \%)$ from $\mathrm{c} 2$ to $\mathrm{c} 3$, and (20\%) from $\mathrm{c} 3$ to c4.

Table 6. Credit stress calculation. Based on the data of the years 2012-2013-2014-2015-2016

\begin{tabular}{|c|c|c|c|c|c|}
\hline Titles & $\mathbf{2 0 1 2}$ & $\mathbf{2 0 1 3}$ & $\mathbf{2 0 1 4}$ & $\mathbf{2 0 1 5}$ & $\mathbf{2 0 1 6}$ \\
\hline Total credits & 4228,2 & 4382,9 & 5156,4 & 5929,9 & 6522,8 \\
\hline $\begin{array}{c}\text { Performing credits } \\
\text { (class 1) }\end{array}$ & 3382,5 & 3506,3 & 4125,0 & 4743,8 & 5218,1 \\
\hline Non-perfoming credits & 845,7 & 876,7 & 1031,4 & 1186,1 & 1304,7 \\
\hline Class 2 & 422,8 & 438,3 & 515,6 & 592,9 & 652,2 \\
\hline Class 3 & 105,8 & 109,7 & 129,0 & 148,4 & 163,2 \\
\hline Class 4 & 317,1 & 328,7 & 386,7 & 444,7 & 489,2 \\
\hline Existing provisions & & & & & 1961,8 \\
\hline Regulatory Capital & 1398,8 & 1450,0 & 1705,9 & 1089.7 & 11988.7 \\
\hline Weighted assets & 7771.3 & 8055.6 & 9477,2 & 20,7 & 19,8 \\
\hline CAR & 14,8 & 15,3 & 18,0 & 0,2 & 0,2 \\
\hline $\begin{array}{c}\text { Non-performing credits / Total } \\
\text { Credits }\end{array}$ & 0,2 & 0,2 & 0,2 & 0,2 & \\
\hline
\end{tabular}

Source: Prepared by the author. 
Table 7. Credit stress results. Based on the data of the years 2012-2013-2014-2015-2016

Unit: in M.AD

\begin{tabular}{|c|c|c|c|c|c|}
\hline $\begin{array}{c}\text { Test } 1: \\
(10 \%) \text { downgrading of performing credits from category } \\
\text { (1to non-performing credits }(4) .\end{array}$ & 2012 & 2013 & 2014 & 2015 & 2016 \\
\hline New-performing & 338,3 & 350,6 & 412,5 & 474,4 & 521,8 \\
\hline Provisions on new non-performing debts & 338,3 & 350,6 & 412,5 & 474,4 & 521,8 \\
\hline Capital post -shock & 862.23 & 932.30 & 1293,4 & 1699.17 & 2064.02 \\
\hline \multicolumn{6}{|l|}{ Impact on RWA/ impact on capital (1\%) } \\
\hline RWA post-shock & 7433,1 & 7705,0 & 9064,7 & 10424,4 & 11466,8 \\
\hline CAR post-chock & 11,6 & 12,1 & 14,2 & 16,3 & 18,0 \\
\hline $\begin{array}{c}\text { Test 2: } \\
\text { Gradual Downgrading of credits from one category to the } \\
\text { other }\end{array}$ & 2012 & 2013 & 2014 & 2015 & 2016 \\
\hline Provisions to be added & 345,9 & 358,5 & 421,8 & 485,1 & 533,6 \\
\hline Capital post-shock & 855.10 & 921.2 & 1284,1 & 1476,7 & 1624,4 \\
\hline Impact on RWA/ impact on capital (\%) & & & & & \\
\hline RWA post-shock & 6718,4 & 6964,2 & 8193,2 & 9422,2 & 10364,4 \\
\hline CAR post-shock & 12.72 & 13.22 & 15.6 & 15.67 & 15.64 \\
\hline
\end{tabular}

Source: Prepared by the author.

Interpreting. The results reflected by the Cooke (CAR) ratio show that the credit risk is very important, its impact is more severe when the adjustment of the provision is taken into account. The results of the tests also enable us to identify that the credit risk generates negative results, reflected by the deterioration of the banking portfolio. This after the downgrading of $10 \%$ of the performing credits from category 01 to category 04 , and as serious the gradual downgrading of credits from one category to another $20 \%$ from $\mathrm{C} 1$ to $\mathrm{C} 2,30 \%$ from $\mathrm{C} 2$ to $\mathrm{C} 3$ and $20 \%$ from $\mathrm{C} 3$ to $\mathrm{C} 4$.

This remarkable drop in the banks' solvency ratio from $18 \%$ to $14 \%$ in 2014 , after the shocks is explained by the fact that the weighted risks are tremendous, although the regulatory capital and these provisions are consequent as well, this does not cover enough the weighted assets.

\subsubsection{Exchange Rate Risk}

\subsubsection{Scenarios}

\section{$5 \%$ Depreciation from DA/€}

$5 \%$ Depreciation from DA/ $\$$

$3,5 \%$ Appreciation from $\mathrm{DA} / €$

\section{$3,5 \%$ Appreciation from DA/\$}

Table 8. Data and results of the exchange rate stress. Based on the data of the years 2012-2013-2014-20152016 Unit: In M.AD

\begin{tabular}{|c|c|c|c|c|c|}
\hline Titles & 2012 & 2013 & 2014 & 2015 & 2016 \\
\hline \multicolumn{6}{|l|}{$\begin{array}{c}\text { Interest sensitive assets (by time } \\
\text { to repricing) }\end{array}$} \\
\hline \multicolumn{6}{|l|}{ Treasury bonds } \\
\hline$<1$ year & 132,2 & 137 & 161,2 & 185,4 & 203,9 \\
\hline \multicolumn{6}{|l|}{ BA deposits } \\
\hline$<1$ year & 956,4 & 991,4 & 1166,40 & 1341,40 & 1475,50 \\
\hline \multicolumn{6}{|l|}{ Credits } \\
\hline$<1$ year & 836,6 & 867,3 & 1020,30 & 1173,30 & 1290,70 \\
\hline \multicolumn{6}{|l|}{$\begin{array}{l}\text { Interest sensitive assets (by time } \\
\text { to repricing) }\end{array}$} \\
\hline \multicolumn{6}{|l|}{ Deposits } \\
\hline$<1$ year & 1473,40 & 1527,30 & 1796,80 & 2066,30 & 2273,00 \\
\hline \multicolumn{6}{|l|}{ Maturity Gap } \\
\hline$<1$ year & 451,9 & 468,4 & 551,1 & 633,8 & 697,1 \\
\hline \multicolumn{6}{|l|}{ Cumulative Gap } \\
\hline$<1$ year & 451,9 & 468,4 & 551,1 & 633,8 & 697,1 \\
\hline \multicolumn{6}{|l|}{ Test: $4 \%$ Interest Rate increase } \\
\hline Net interest income impact & 9 & 9,4 & 11 & 12,7 & 13,9 \\
\hline Regulatory capital before shock & 1398,80 & 1450,00 & 1705,90 & 1961,80 & 2158,00 \\
\hline
\end{tabular}


Table 8 (cont.). Data and results of the exchange rate stress. Based on the data of the years 2012-2013-20142015-2016 Unit: In M.AD

\begin{tabular}{|c|c|c|c|c|c|}
\hline Regulatory capital after shock & 1382,20 & 1432,80 & 1685,60 & 1938,40 & 2132,30 \\
\hline CAR before shock & 23.4 & 21.5 & 16 & 18.4 & 18.9 \\
\hline RWA before shock & 7787,00 & 8071,90 & 9496,30 & 10920,70 & 12012,80 \\
\hline CAR Post-shock & 23.2 & 21.3 & 15.84 & 18 & 18.32 \\
\hline
\end{tabular}

Source: Prepared by the author.

Interpreting. These results show a weak exchange position of the Dinar against other currencies (reminding that a foreign exchange exposure is the difference between the outputs and the inputs of the currencies).

This weakness translated by these facts:

* The absence of currency forward markets.

* The absence of hedging instruments against the exchange risk (options, swaps...)

* The absence of foreign currencies monetary market, while it is of utmost importance for hedging operations.

* A weak constitution of banks cash flow in foreign currency, which greatly reduces the dynamism of the foreign exchange market. Adding to all this and with equal priority, the fact that the Euro is widening more and more the gap with the Dollar.

This level of parity of the European currency against the Dollar is not close to recovery in the future. This difference in favor of the Euro will be reflected clearly on our trade balance, since we export mainly in Dollar and we import largely in European currency, not to mention, the level of currency transfer by our counters living abroad. This is translated by tangible losses, which the state must suffer.

Nevertheless, the strategy of deleveraging, followed by the sharp reduction in external debt, mainly in 2009, allowed for a good use of resource surpluses. The period between 2004-2012 was particularly marked by a strong accumulation of official foreign exchange reserves, thanks to hydrocarbon exports and despite the intensification of the international financial crisis in 2008, therefore this is what contributed to limit the risk of contagion, as well as the external shock effect by acting as a protective shield.

\subsubsection{Interest rate risk}

\subsubsection{Scenario}

$4 \%$ decrease in interest rate

Table 9. Data and results of interest rate stress. Based on the data of years 2012 -2013-2014-2015-2016

Unit: In M.AD

\begin{tabular}{|c|c|c|c|c|c|}
\hline Titles & 2012 & 2013 & 2014 & 2015 & 2016 \\
\hline \multicolumn{6}{|c|}{ Interest sensitive assets (by time to repricing) } \\
\hline \multicolumn{6}{|c|}{ Treasury bonds } \\
\hline$<1$ year & 132,2 & 137,0 & 161,2 & 185,4 & 203,9 \\
\hline \multicolumn{6}{|l|}{ BA deposits } \\
\hline$<1$ year & 956,4 & 991,4 & 1166,4 & 1341,4 & 1475,5 \\
\hline \multicolumn{6}{|l|}{ Credits } \\
\hline$<1$ year & 836,6 & 867,3 & 1020,3 & 1173,3 & 1290,7 \\
\hline \multicolumn{6}{|c|}{ Interest sensitive assets (by time to repricing) } \\
\hline \multicolumn{6}{|l|}{ Deposits } \\
\hline$<1$ year & 1473,4 & 1527,3 & 1796,8 & 2066,3 & 2273,0 \\
\hline \multicolumn{6}{|l|}{ Maturity Gap } \\
\hline$<1$ year & 451,9 & 468,4 & 551,1 & 633,8 & 697,1 \\
\hline \multicolumn{6}{|l|}{ Cumulative Gap } \\
\hline$<1$ year & 451,9 & 468,4 & 551,1 & 633,8 & 697,1 \\
\hline \multicolumn{6}{|c|}{ Test $: 4 \%$ Interest Rate increase } \\
\hline Net interest income impact & 9,0 & 9,4 & 11,0 & 12,7 & 13,9 \\
\hline Regulatory capital before shock & 1398,8 & 1450,0 & 1705,9 & 1961,8 & 2158,0 \\
\hline Regulatory capital after shock & 1382,2 & 1432,8 & 1685,6 & 1938,4 & 2132,3 \\
\hline CAR before shock & 23.4 & 21.5 & 16 & 18.4 & 18.9 \\
\hline RWA before shock & 7787,0 & 8071,9 & 9496,3 & 10920,7 & 12012,8 \\
\hline CAR Post-shock & 23.2 & 21.3 & 15.84 & 18 & 18.32 \\
\hline
\end{tabular}

Source: Prepared by the author.

Interpreting. We want to reiterate the fact that it was done as an illustration, because interest rates in Algeria are fixed $(\mathrm{Tx}=4.25 \%)$. Through our test, we have assumed the opposite and therefore we have exposed the 
banking sector to a variation, which is an increase in interest rates on assets and liabilities in Dinars, we then found that interest rates were floating.

Nevertheless, we allow ourselves to say that the provisions governing the financial market inevitably require a fundamental revision. The current situation of the financial market is considered unbearable. The market is characterized by weariness in front of the long wait of listing the companies to the stock exchange and the stimulus of Algiers' Stock Exchange. This situation stands out as a perfect obstacle to the emergence of an efficient financial market capable of responding to its concerns in relation to the financing of companies.

\section{Discussion}

Given the current economic context, which is regularly shaken by crises, banks that will be able to set up a monitoring procedure in a central scenario analysis framework may, undoubtedly, optimize their strategy, they have a Competitive and essential advantage over their competitors.

Through this work, we tried to set up a stress test procedure. The problematic related, upstream, to the collection of data and the use of the method, as well as the consequences that may result, downstream, have been identified and analyzed. It should be noted that a scenario analysis infrastructure could truly become a driving force in the decision-making process.

This approach will enable bank decision-makers to identify in real time the main risks, to which they are exposed to anticipate it. By putting in place protective and corrective measures, to understand the effects that strategic decisions will have on the balance sheet, according to different economic assumptions and to control in the evolution time of the effective performance compared to the initial objectives.

In fact, it is necessary to be able to collect data from all financial institutions, with sufficient and reliable details, because the condition of the effectiveness of a scenario analysis platform is to have a centralized database, sufficiently large, powerful and flexible to allow consolidation:

The whole of bank counterparties and their financial data,

Of the different types of assets and debts,

Of market economic data,

Any information that could have a significant impact on cashflow, income statement, capital requirements, Capital and risk-adjusted performance.

Having a performing scenario analysis infrastructure is essential to achieve:

More certain strategic decisions.

Identify risks and deficiencies of the banks' current strategy.

Define and document appropriate response mechanism for the main categories of risks.

Assess the advantages and risks of the different alternative strategies.

$>$ Define and weigh the main orientations and in view of the increasing requirements in capitals, which are profiling.

Be able to deploy the capital as effectively as possible to reach the yield sought.

To further increase this efficiency, the scenario analysis platform will be placed at the center of the risk management infrastructure of financial institutions. The storehouse of financial and risk data will thus provide the basic elements of the analysis.

The operational systems will enable the implementation of strategic and planning assumptions by defining risk limits, objectives and prices that will apply to new loans granted by the bank. The latter will in turn feed the database, which will update the control and monitoring information, necessary for a regular review and possibly adjust the strategy.

\section{Conclusion}

The purpose of this study is to provide a new vision, a realistic and precise application in risk management within the Algerian banking sector. The purpose of the stress test is to anticipate both the risks and the capital 
required for the coming months or years, taking into account possible shocks, whether they are economic or based on assumptions internal to the bank. .

Thus, the definition and calculation of stress scenario impacts is a very relevant steering tool, and informs decision-makers of the consequences that their strategic choices might have. This is why this tool deserves to be managed by a centralized infrastructure, within a framework allowing institutions to optimize their strategy.

The study on the Algerian banking system showed that the best way to apply stress tests effectively was to collect and consolidate the appropriate data. The results are here, the future will tell us if the stress tests will be applied in a constant and permanent way.

Stress tests showed their performance, reflecting the exact position of capital after a pessimistic shock. The diversity of the shocks represents the strong point of the stress tests; it is indeed a principle of adaptation with any macro-microeconomic environment. It is enough to interpret the results in a clear and comprehensive way to make a strategic decision. Resistance testing is an effective tool in decision making. They appear in different approaches or standards, whether qualitative or quantitative.

In Algeria, stress tests are far from performing well due to several reasons. A weak banking data infrastructure limits the optimal application of stress tests. Hence, insufficient training of banking staff to master the tools for analysis and application of stress tests. That is why, Algerian monetary supervisors should continue to progress in the area of risk management, applying various mechanisms.

\section{References}

1. Baghli M, Brunhes-Lesage V, Bandt O, Fraisse H and Villetelle J-P, Mascotte. (2004). Quarterly Conditions Analysis and Forecast Model, Bank of France, Study and Research Notes, 106.

2. Diamond D., Dybvig P. (1983). Bank runs, Deposit Insurance, and liquidity, Federal Reserve Bank of Minneapolis, Quarterly Reviews, 2(1).

3. Eichengreen B, Arteta C. (2000). Banking Crises in Emerging Markets: Presumptions and Evidence, Institute of Business and Economic Research, Center for International and development Economics Research, University of California.

4. Flannery M.J. (1981). Market interest rates and commercial bank profitability: An empirical investigation, Journal of Banking and Finance.

5. Martin Čihák. (2007). Introduction to Applied Stress Testing, IMF Working Paper, WP/07/59.

6. Mathieu Gbêmèho TRINNOU, 2012, Implementation of the macroprudential «stress-test » of the Banking Credit Risk in The West African Economic and Monetary Union (UEMOA), Studies Centres of Training and Research in Development, (CEFRED) Faculty of Economic Science and Management (FASEG) University of Abomey- Calavi, Benin.

7. Olivier DE BANDT, Vichett OUNG. (2004). Stress Tests Statement conducted on the French Banking System.

8. Stavors Peristian, Donald P. Morgan et Vanessa Savino. (July 2010). The information value of the stress test and bank opacity, Federal Reserve Bank of New York Staff Reports, 460.

9. Vincent MARTIN, Santiago TAVOLARO and Sandrine VIOL. (January 2013). Stress Tests on the Banking system and the Insurance Bodies in France, the Bank of France Magazine, 11.

\section{Reports and sites}

1. https://www.researchgate.net/publication/276268740, consulted on the 20/12/2017.

2. http://www.abcbourse.com/apprendre/19 bottom up top down.html, consulted on the 12/12/2016.

3. http://www.cna.dz/Actualite/Chiffres, consulted 03/01/2017.

4. http://www.sgbv.dz/?page=rubrique\&lang $=\mathrm{fr} \& \bmod =20$, consulted on the $02 / 01 / 2017$

5. Report of the FMI Financial Stability Assessment No. 14/161, Algeria

6. SAS Report, Accenture Management consulting. (2012). 